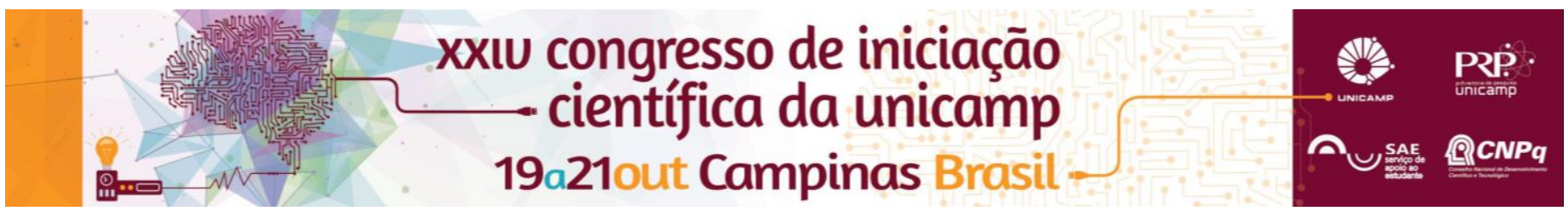

(Ex)posta: pornografia de vingança e a intimidade das mulheres na Internet.

\title{
Daniella Orsi da Silveira*.
}

\section{Resumo}

Esta pesquisa propõe uma reflexão sobre a "pornografia de vingança", fenômeno da publicização da intimidade sem o consentimento de suas protagonistas, perguntando como as convenções de gênero, articuladas a outras diferenças, operam na veiculação e recepção de imagens íntimas, motivando julgamentos morais sobre as mulheres expostas. Para isso, foram analisadas a produção, a circulação e o consumo dessas imagens, incluindo comentários sobre elas. Esse material aponta para percepções, de um lado, sobre a pornografia de vingança como prática violenta e, de outro, para os lugares dos corpos femininos na Internet, pensados como passíveis de julgamentos morais quando associados ao exercício da sexualidade.

\section{Palavras-chave \\ Gênero, Internet, Pornografia de Vingança.}

\section{Introdução}

Pornografia de vingança ou pornografia de revanche nomeiam a disseminação não consensual de imagens íntimas, de nudez ou sexo, através da Internet e redes sociais, com a intenção de tornar pública a intimidade de suas protagonistas. A maioria das imagens nesse contexto é de mulheres e são produzidas, a princípio, com consentimento em relacionamentos afetivo-sexuais heterossexuais; porém, com o rompimento da relação, os ex-parceiros divulgam esses conteúdos sem autorização, com o intuito de humilhálas, muitas vezes expondo suas informações pessoais.

As discussões geradas pelas notícias de casos de pornografia de vingança apontam para convenções de gênero, cujas articulações com outras categorias de diferenciação motivam julgamentos morais sobre as mulheres expostas. Esses julgamentos são observados não só a partir da produção da notícia e seus comentários, mas também são percebidos pelas mulheres que relatam essa violência: ainda que essas imagens circulem em grupos restritos ou em sites especializados, muitas das ofensas são dirigidas diretamente a elas. Nesse sentido, a questão central desta pesquisa é compreender como as convenções de gênero privilegiam maneiras de olharmos para esses corpos e essas mulheres.

\section{Resultados e Discussão}

Através de relatos concedidos por vítimas de pornografia de vingança e de comentários dirigidos a mulheres expostas em notícias de jornais, reportagens e sites considerados pornográficos, a pesquisa centrou-se na análise da produção, circulação e consumo das imagens publicizadas. Dessa maneira, procurou-se compreender como o conceito é construído na Internet e como é percebido a partir de diferentes vozes.

A pornografia de vingança revela uma estreita relação com o universo pornográfico, sobretudo online e amador, em seções dedicadas à divulgação de "exnamoradas"1. Pornografia de revanche remete a ideia de um adversário derrotado, com anseios de vingança. Assim, alguns agressores parecem movidos por um sentimento de retaliação: a exposição seria uma espécie de castigo ou punição para a "ex-companheira".
A humilhação é reforçada por adjetivos que acompanham essas publicações - "vadia", "puta", "safada". Esses termos, que acionam moralidades, reforçam a ideia de lugares apropriados para mulheres no exercício de sua sexualidade e parecem afastar as mulheres expostas de noções de vulnerabilidade e até de empatia e comoção - mesmo quando o consentimento na produção, que remete à intimidade, é estendido para o consumo público.

Desse modo, a pornografia de vingança sustenta um discurso violento, que hierarquiza tipos de feminilidade, colocando em polos opostos "honestas" e "desonestas", retomando a clássica dicotomia entre "divinas" e "impuras"2. Ao contrário do agressor, seja nas notícias, seja nos comentários, a conduta e, inclusive, a vida pessoal das mulheres que "caíram na net" é o foco dos debates e, no geral, buscam responsabilizar as vítimas pela exposição ${ }^{3}$, de modo a justificar a prática.

\section{Conclusões}

Reduzidas ao olhar sobre sua sexualidade, as mulheres que "caíram na net" remetem a noções de corpos femininos que ora servem para a humilhação, ora para a diversão e excitação - ideia muito contestada nos relatos das mulheres expostas, que reivindicam autonomia e liberdade sexual. Dessa forma, a prática da violência, materializada na pornografia de vingança, reproduz formas de pensar normativas e hierarquizadas sobre os lugares das mulheres na sociedade, particularmente no tocante ao exercício da sexualidade.

\section{Agradecimentos}

Agradeço ao PIBIC e ao SAE/UNICAMP, ao Núcleo de Estudos de Gênero - Pagu, à minha orientadora lara Beleli e às mulheres que concederam entrevistas para esta pesquisa.

\footnotetext{
${ }^{1}$ LINS, Beatriz A. Caiu na rede é crime: controvérsias sobre a "pornografia de vingança”. IV ENADIR, GT.5 - Antropologia, gênero e punição, 2015.

${ }^{2}$ SIBILIA, Paula. A nudez autoexposta na rede: deslocamentos da obscenidade e da beleza?. Cad. Pagu, Campinas. n.44. p.171-198, Junho 2015.

${ }^{3}$ BELELI, Iara. Novos cenários: entre o "estupro coletivo" e a "farsa do estupro" na sociedade em rede. Cad. Pagu, Campinas. n.47. No prelo.
} 